\title{
Review
}

【日本小坚循環器学会功労賞記念寄稿 5】

\author{
胎児循環器断面像：卵円孔，静脈管，肺循環路の出生変化 \\ 門間 和夫 \\ 東京女子医科大学循環器小児科
}

\section{Fetal and Neonatal Cardiovascular Cross-Sectional Morphology in the Rat: The Foramen Ovale, Ductus Venosus, Right Ventricle, and Pulmonary Artery}

\author{
Kazuo Momma \\ Department of Pediatric Cardiology, Tokyo Women's Medical University, Tokyo, Japan
}

\begin{abstract}
This review examines the natural-colored, cross-sectional morphology of the foramen ovale (FO), ductus venosus (DV), right ventricle (RV), and pulmonary artery (PA) in fetal and neonatal rats. The ductus arteriosus (DA) and congenital heart disease are reviewed separately. The in situ cross-sectional morphology of fetal and neonatal rat hearts was studied by rapid whole-body freezing, slicing on a freezing microtome, and serially photographing the cross-sections every $0.5 \mathrm{~mm}$ with a stereoscopic microscope (Wild M400). The serial frontal sections of the fetal thorax and upper abdomen showed the fetal oxygenated blood route including the umbilical vein, DV, inferior vena cava, posterior right atrium, FO, and left atrium. Neonatal frontal sections of the same area revealed closure of the DV, FO, and DA, in addition to rapid enlargement of the peripheral pulmonary vessels. Neonatal closure of the FO was associated with remarkable growth of the atrial septum flap. The fetal atrial septum was short and thin at the FO, and the flap tip only just reached the rim of the FO. Neonatally, this atrial septum grew rapidly in length and thickness within two days, closing the FO.
\end{abstract}

Keywords: fetus, foramen ovale, ductus venosus, right ventricle, pulmonary artery

本稿では胎児特有の循環路の出生時変化をラット凍結断面カラー写真の図譜で提示する. 動脈管と先 天性心疾患は紙面の都合で別の図譜にまとめた。 ラット胎仔と新生仔を全身急速凍結法で固定し凍結 ミクロトームで胸部を前額面, 矢状面, 横断面で切り, $0.5 \mathrm{~mm}$ 毎に断面カラー写真を連続撮影した. これにより胎児エコー図のモデルになる鮮明な天然色画像が得られた。 心臟短軸断面で下大静脈右房 開口部から卵円孔を経て左房への胎生期酸素化血の主要血流路が 1 断面に明示された. 胸部矢状面で も臍静脈-静脈管-下大静脈-右房-卵円孔-左房の断面が描出された. 新生仔の前額面では動脈管と卵円 孔の閉鎖が明示された．胎仔で短い薄い卵円孔部心房中隔は生後 2 日で急速に進展肥厚して卵円孔を 閉鎖した．胎生期心臟連続断面では太い動脈管，大きい胸腺，大きい右房と左房が明示された．いず れの断面図でも出生後に左右肺動脈末梢と肺静脈の急速な拡大, 左右心室の拡大, 右室壁菲薄化, 肺 の拡張, 右心系のチアノーゼと左心系の動脈血化が明示された.

著者連絡先：=162-8666 東京都新宿区河田町 8-1＼cjkstart東京女子医科大学循環器小児科＼cjkstart門間和夫（E-mail: kmomma@iris.ocn.ne.jp） doi: $10.9794 /$ jspccs.34.165 


\section{はじめに}

小児循環器学で胎児心臓病学はますます重要にな り, 最近本誌に初めて胎児循環生理が Reviewされ た ${ }^{1)}$ 。この Review で明らかなのは胎児循環の生理は ヒト胎児で研究することが困難なため, 主に動物(羊) で研究 ${ }^{2)}$ されたことである. 胎児循環の解剖も同様 ${ }^{3)}$ である. 胎児循環は卵円孔, 動脈管, 静脈管など特 有の循環路を持ち, これらは臨床上不鮮明ながら胎児 エコーで観察 ${ }^{4)}$ されている. 動物実験ではラットと 全身急速凍結法を用いると胎生期循環路の鮮明な天 然色の生体断面写真が得られる. この実験法は Karolinska 研究所で開発され ${ }^{5)}$, 私は 40 年間動脈管の薬 理学の研究 ${ }^{6}$, 心臓と大血管の出生時の形態変化の研
究 $^{7-12)}$, 先天性心疾患の形態研究 ${ }^{13-15)}$, 静脈管の研 究 ${ }^{11)}$ に用いてきた。 心蔵断面画像はヒト胎児エコー のモデルにもなる．私はこれらの画像を白黒写真で発 表したが, 天然色断面画像の大部分は未発表なので, ここに図譜として発表する。 な抬胎生期先天性心疾患 及び動脈管の断面像は別の論文 ${ }^{14,15)}$ にまとめた．そ れぞれの実験の数字データは紙面の関係で省略するの で，原著論文 ${ }^{6-13)}$ を参照されたい.

\section{方法}

ラット満期胎仔の全身急速凍結法による実験 ${ }^{6-12)}$ を次のように行った. ラットの妊娠期間は 21.5 日な ので，妊娠 21 日目に親ラットを頸椎脱臼法で安楽死
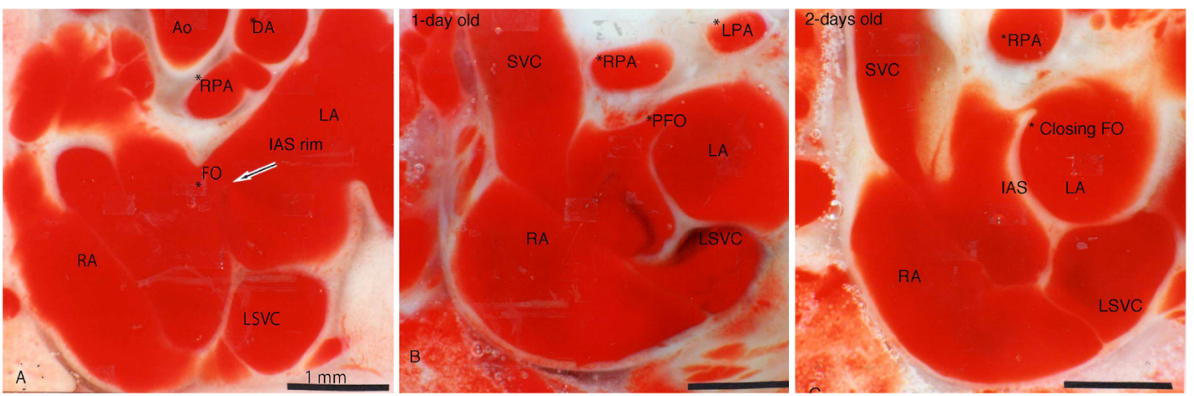

Fig. 1 Frontal sections of the atrial septum of a rat fetus (A), a 1-day old rat (B), and a 2-day-old rat (C) Abbreviations used in the figures. A: anterior. Ao: aorta. AoV: Aortic valve. Ca: caudal. Cr: cranial. DA: ductus arteriosus. DAo: descending aorta. DV: ductus venosus. E: esophagus. FO: foramen ovale. HV: hepatic vein. IAS: interatrial septum. IVC: inferior vena cava. L: left. LA: left atrium. LB: left bronchus. LPA: left pulmonary artery. LSVC: left superior vena cava. MPA: main pulmonary artery. p: posterior. PFO: patent foramen ovale. PoV: portal vein. PV: portal vein, pulmonary vein. PVa: pulmonary valve. LPA: left pulmonary artery. LPV: left pulmonary vein. R: right. RA: right atrium. RPA: right pulmonary artery. RV: right ventricle. RVI: right ventricular infundibulum. SVC: superior vena cava. T: trachea, thymus. US: umbilical sinus. UV: umbilical vein.

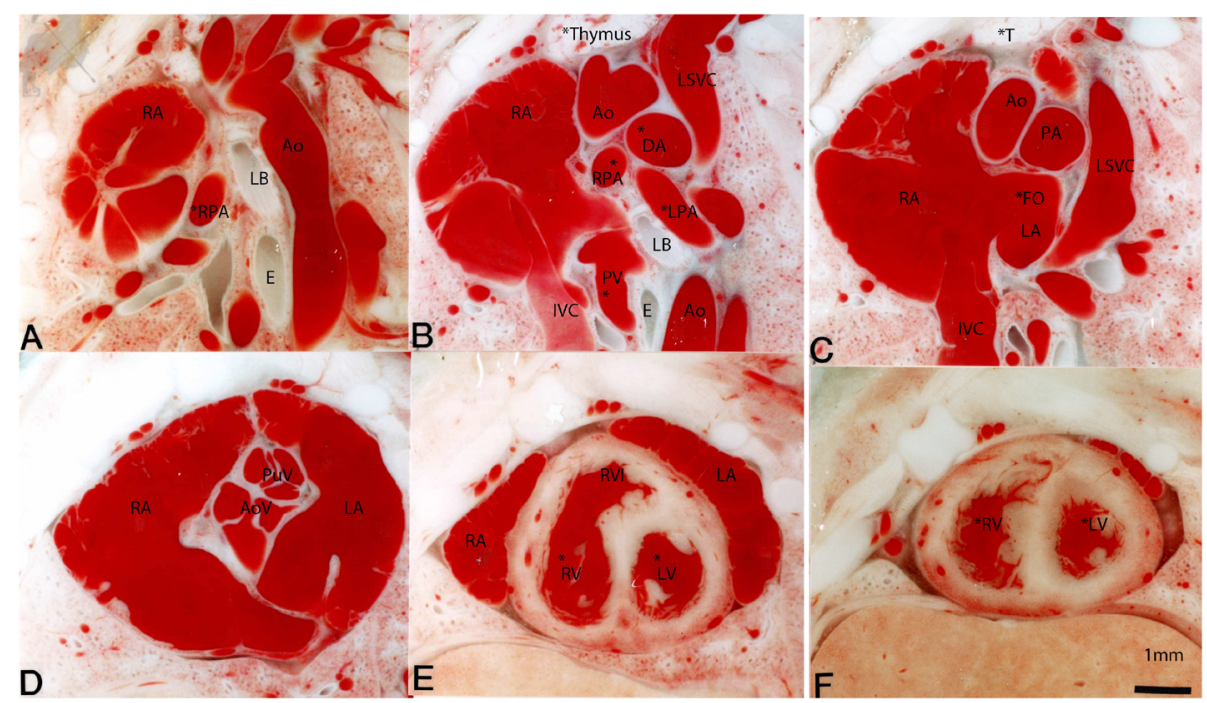

Fig. 2 Serial cardiac short-axis sections of a rat fetus 

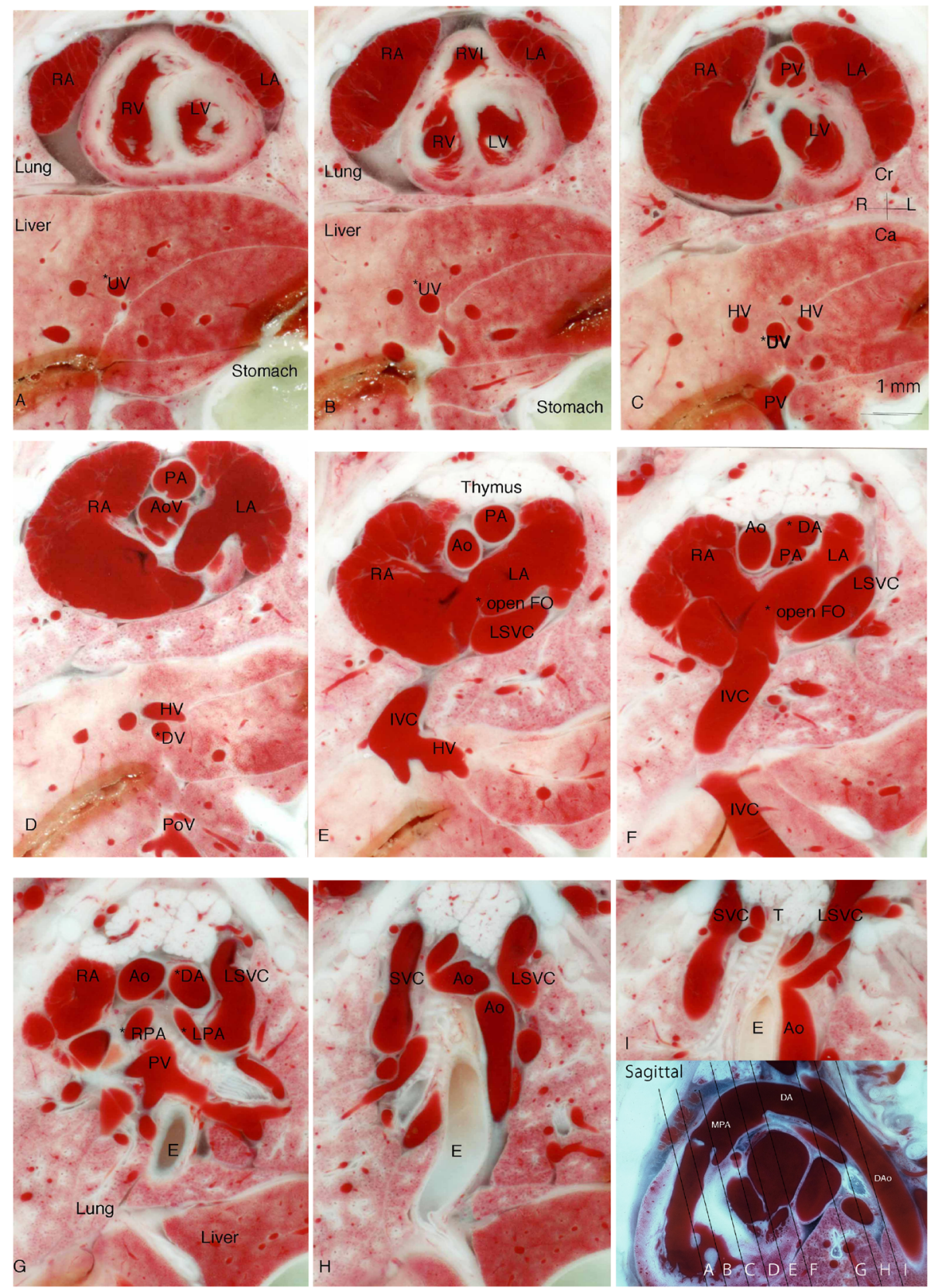

Fig. 3 Serial frontal sections of the heart and liver of a normal rat fetus. The final panel shows a sagittal section indicating the section planes for sections (A) to (I)

させ，ただちに帝王切開で取り出した胎仔を胎盤つき のままドライアイスーアセトン $\left(-76^{\circ} \mathrm{C}\right)$ に投入して 瞬時に凍結した。凍結した胸部を凍結ミクロトーム で前額面 frontal, 矢状面 sagittal, 横断面 transverse section，または心蔵短軸面 cardiac short sxis で切り, 0.1 乃至 $0.5 \mathrm{~mm}$ 毎に実体顕微鏡（Wild M400）と力 ラーフィルム（Reale，富士フィルム）で撮影した。 1 個体の胸部から約 20 断面を撮影した. 生後 $1 \sim 4$ 日 後のラットは予定日に自然出産後に親の保育授乳中の
ラットを用いた。

ラットの解剖学書 ${ }^{16)}$ によるとラットとヒトでは心 臓と胸部大血管の解剖は大体共通しているが, 次の種 差がある. 冠状静脈洞に還流する左上大静脈はヒトで は疾患として生じるがラットなどげっ歯類では正常で ある. 左右の肺静脈はヒトでは胎生期後半以後は左右 2 本ずつ左房に入る ${ }^{17)}$ が，ラットでは左房後方で合 流して共通肺静脈になり，左房に接続する，臍動脈は ヒトでは 2 本あるがラットでは 1 本である．臍静脈 


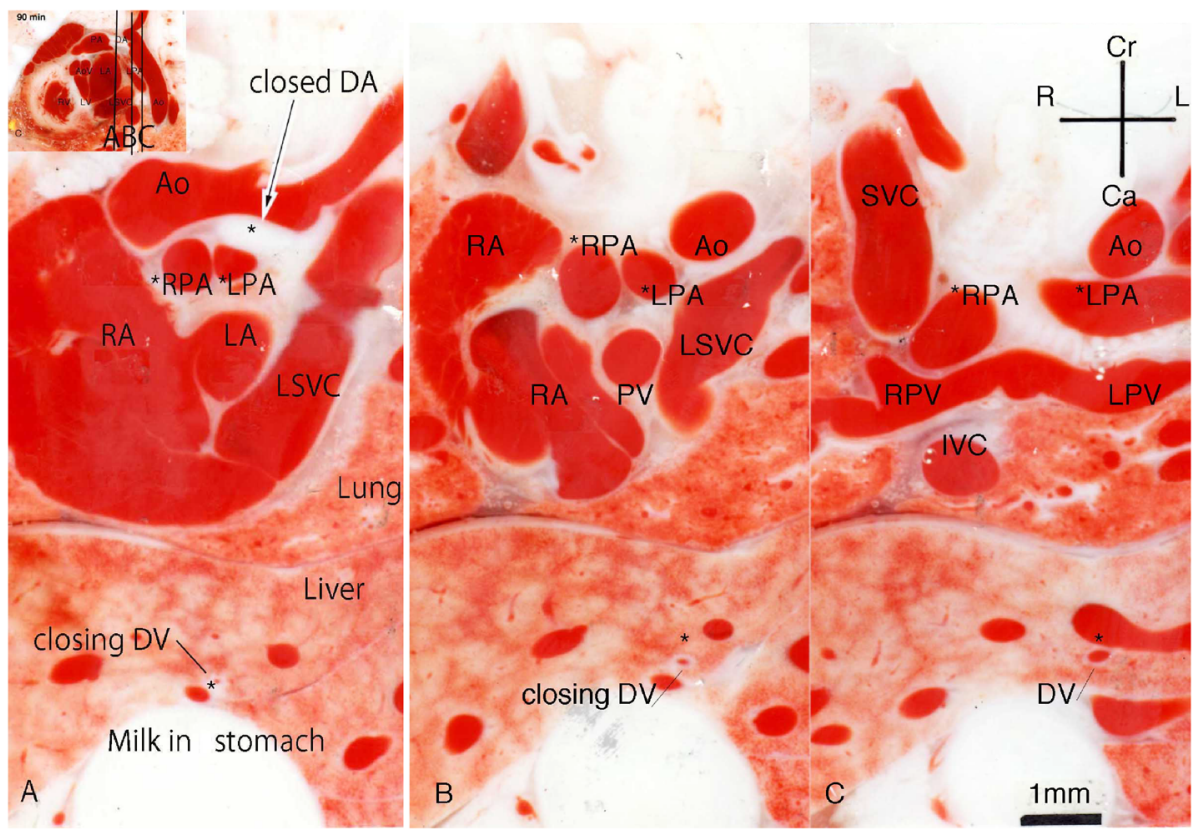

Fig. 4 Serial frontal sections of the posterior heart and liver of a 1-day-old rat
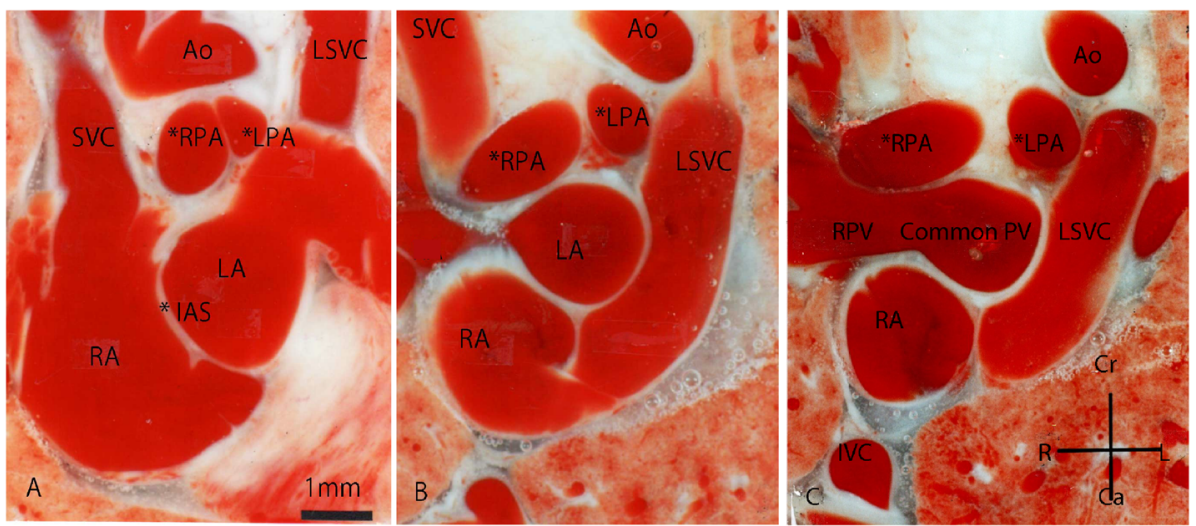

Fig. 5 Serial frontal sections of the posterior heart of a 4-day-old rat

の腹壁から静脈管までの走行はヒトでは肝蔵下面であ り，ラットでは肝臓下面と横隔膜の中間で肝蔵内であ る.

\section{心臓血管断面写真}

図中の重要な部位には*印を付した.

Fig. 1 は胎仔と新生仔の卵円孔の前額面断面であ る. 胎仔の卵円孔部の心房中隔 flap は薄く, 左房側 に開いているが，生後 2 日で厚く長くなり，閉鎖す る. 左右肺動脈は生後急速に拡大する.

Fig. 2 はラット胎仔心臓の短軸面断面を心室部(F) より順次心基部（肺動脈弁と大動脈弁部）（D）を経て
主肺動脈部 $(\mathrm{C})$ 大動脈弓部 ( $\mathrm{B}, \mathrm{A})$ へ切り撮影した. C には胎仔の動脈血の血流路：下大静脈-右房後部-卵 円孔-左房が明示されている，右室は左室室と同じ壁 厚を持ち容積は左室よりやや大きい（E，F）。左右肺 動脈径は主肺動脈径の半分である.

同じ所見はFig. 3 でも見られる. Fig. 3 は胎仔の心 臓と肝臓の前額面図である。ほぼ同じ太さの動脈管, 大動脈, 肺動脈の断面像が示されている. 臍静脈血が 静脈管-卵円孔-左房へ流れる道筋 ${ }^{14)}$ が(F)に示され ている。細めの左右肺動脈が $(G)$ に明示されている.

Fig. 4 は生後 1 日の新生仔心臓後部と肝臓の前額 面, Fig. 5 は生後 4 日の新生仔である. 静脈管 ${ }^{3)}$ は閉 鎖し, 左右肺動脈の急速な生後の拡大 ${ }^{7)}$ がある.た 


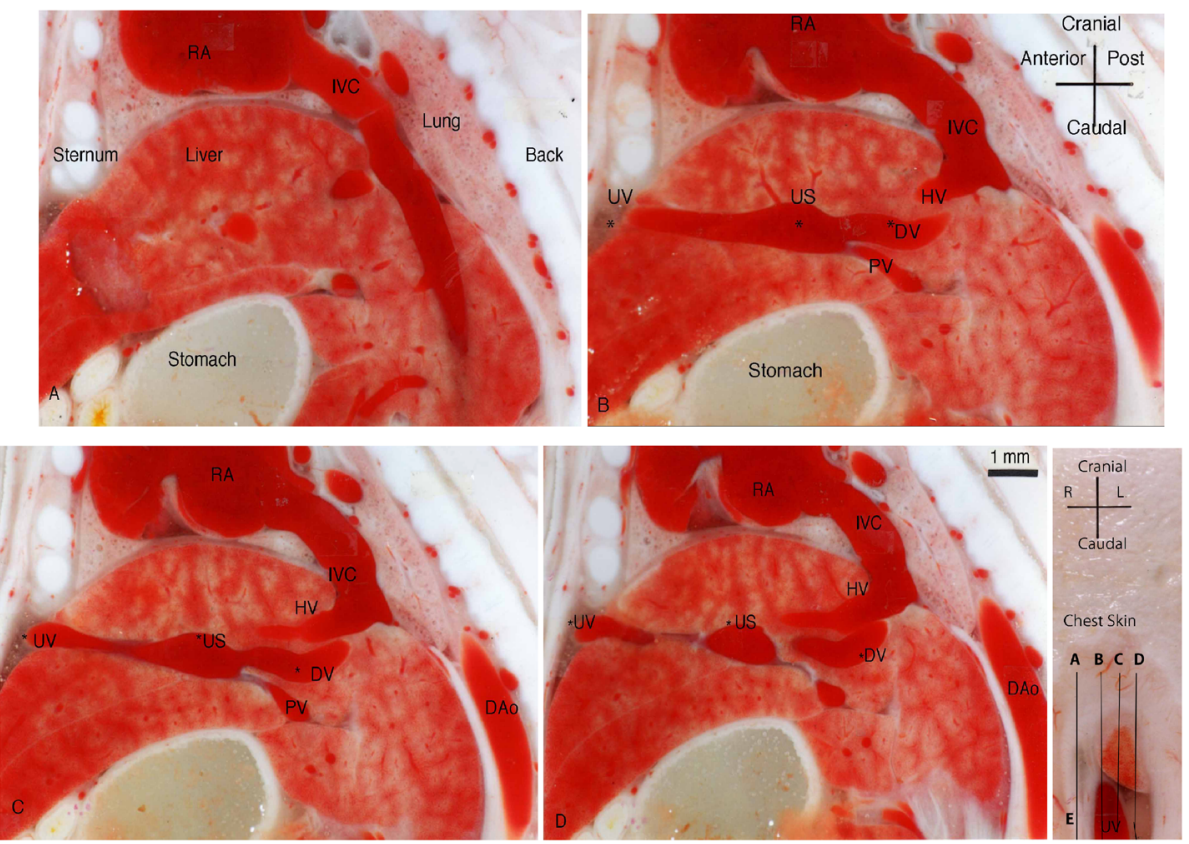

Fig. 6 Serial sagittal sections of the umbilical vein, umbilical sinus, portal vein, ductus venosus, and inferior vena cava of a rat fetus. The cutting planes are shown in $\mathrm{E}$

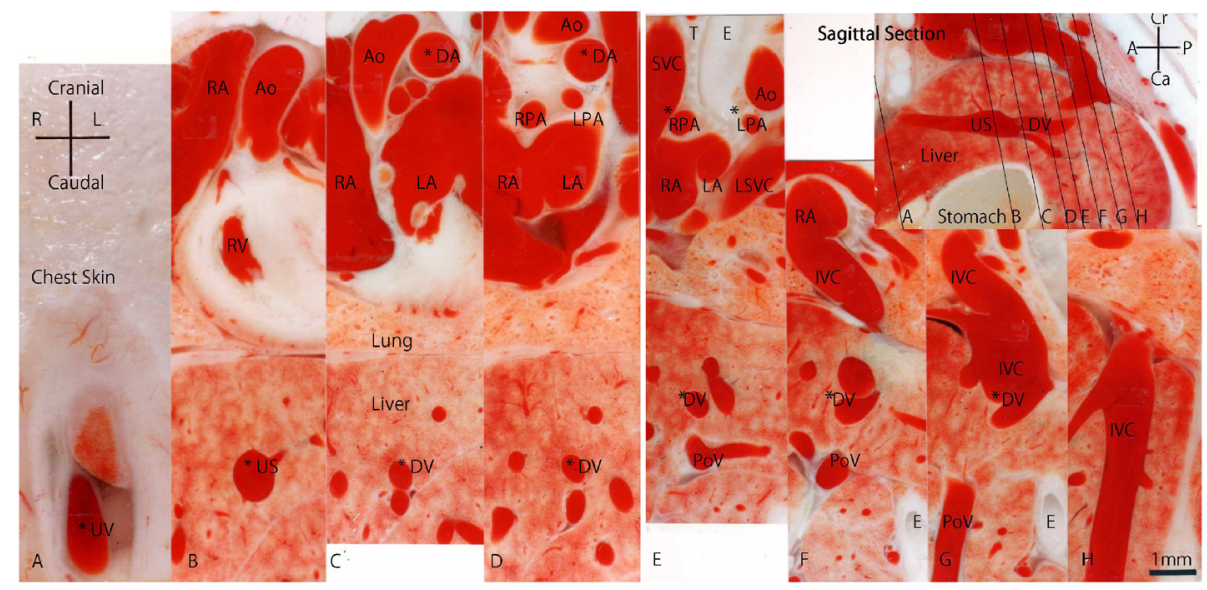

Fig. 7 Serial frontal sections of the fetal heart and liver showing the open fetal channels: the ductus arteriosus, right and left pulmonary arteries, umbilical sinus, ductus venosus, and foramen ovale. The cutting planes are shown in the upper right corner

だし左右肺動脈起始部（Fig. 4A, Fig. 5A）は特に左肺 動脈で末梢部より細い ${ }^{7}$.

Fig. 6 と Fig. 7 はラット胎仔の臍静脈, 静脈管 7,11$)$ を示す。ヒトの静脈管は腹壁から肝臟下面を背中方向 へ走行するが，ラットの臍静脈 ${ }^{3)}$ は前腹壁から肝臓 内を背中方向へ走行する.

Fig. 8 と Fig. 9 はラット胎仔と新生仔（生後 2 日） の胸部横断面である. 新生仔では胎仔のチアノーゼが なくなり，動脈管は閉じ，肺は拡張し，右房と左房は
やや小さく, 右室と左室は拡張し, 右室壁は薄い ${ }^{10)}$.

\section{おわりに}

臨床で新生児の心エコーをとると，小さい心房中隔 欠損がしばしば見つかるが，ここに提示したラットで の断面図から卵円孔自然閉鎖機転は明らかで，この種 の心房中隔欠損の良性の予後が理解される．新生児 の機能性雑音の一つが左肺動脈起始部狭窄から生じ, 


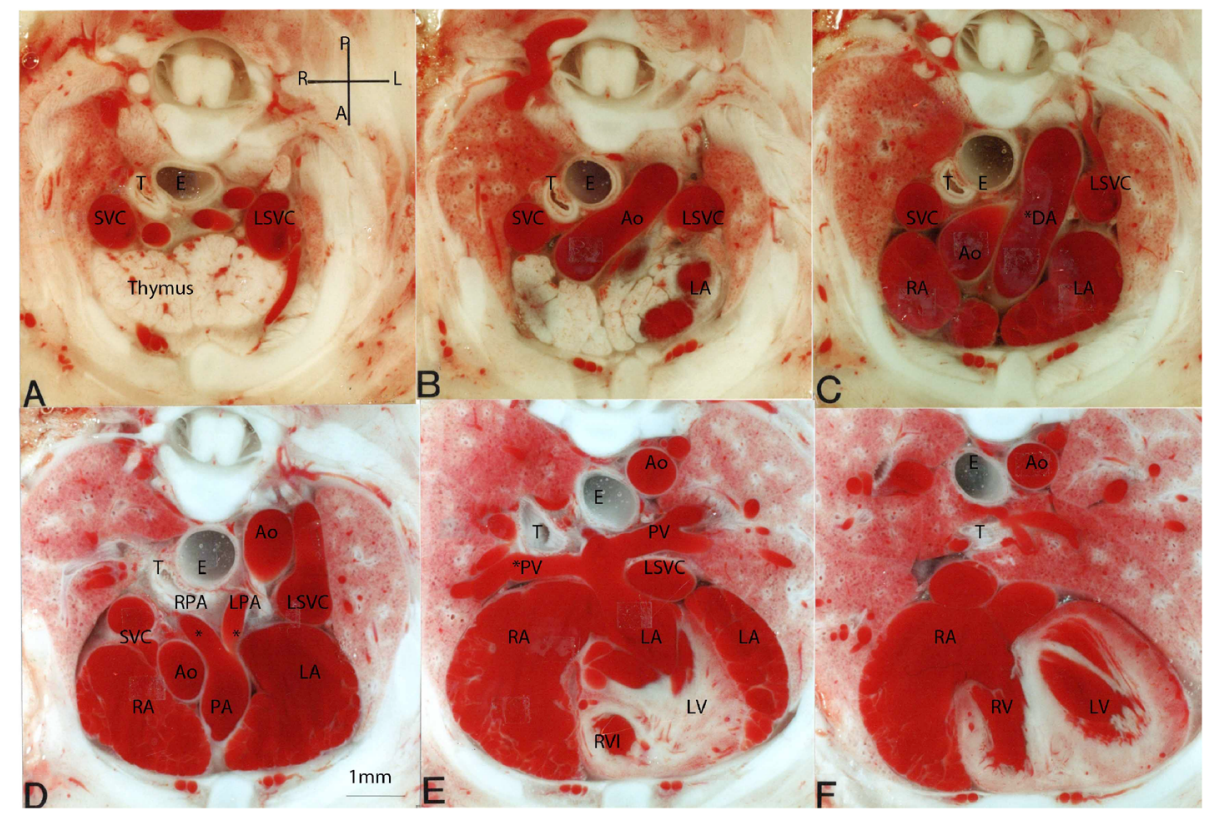

Fig. 8 Serial thoracic transverse sections of a normal rat fetus
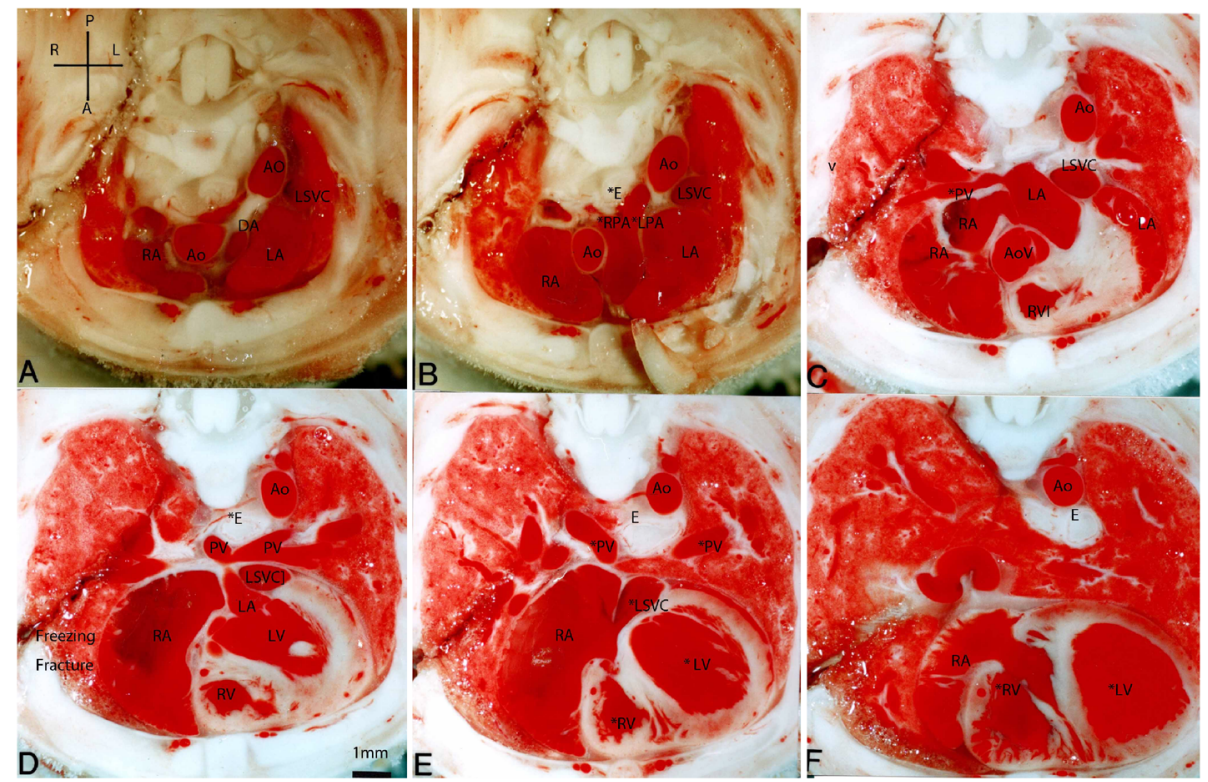

Fig. 9 Serial thoracic transverse sections of a 2-day-old rat

ラット新生仔の肺動脈断面像に狭窄がでている。ラッ トの胎生期間は 7 日でヒトの 7 か月に相当し, 胎仔 と新生仔の成長はヒトより数十倍速やかであり, 循環 器の発達と変化も速やかである.

\section{利益相反}

利益相反に関して記載すべき事項はありません。

\section{引用文献}

1）稲村 昇：胎児循環生理. 日小児循環器会誌 2016; 32: 451-461

2) Rudolph AM: Congenital Diseases of the Heart: Clinical-Physiological Considerations. Third Ed., Chichester, UK, Wiley-Blackwell, 2009, pp 1-24

3) Polin RA, Fox WW, Abman SH: Fetal and Neonatal Physiology. Fourth Ed., Philadelphia, Elsevier, 2011

4) Yagel S, Silverman NH, Genbruch U (eds): Fetal Cardiology. Martin Denitz, London, 2003

5) Hörnblad PY, Larson KS: Studies on closure of the ductus 
arteriosus 1: Whole-body freezing as improvement of fixation proceedures. Cardiologia 1967; 51: 231-241

6）門間和夫：動脈管薬の実験 40 年. 日小児循環器会誌 2016; 32: 261-269

7) Momma K, Ito T, Ando M: In situ morphology of the ductus venosus and related vessels in the fetal and neonatal rat. Pediatr Res 1992; 32: 386-389

8) Momma K, Ito T, Ando M: In situ morphology of the aorta and common iliac artery in the fetal and neonatal rat. Pediatr Res 1993; 33: 302-306

9) Momma K, Ito T, Mori Y, et al: In situ pulmonary vascular morphology and lung volume in the fetal and neonatal rat. Early Hum Dev 1993; 34: 191-198

10) Momma $K$, Takao A, Ito $R$, et al: In situ morphology of the heart and great vessels in fetal and neonatal rats. Pediatr Res 1987; 22: 573-580

11) Takeuchi D, Momma K: Effect of decreased umbilical blood flow and hemorrhage, and decreased prostaglan- dins on the ductus venosus diameter in the rat. Biol Neonate 2006; 89: 42-49

12）閃間和夫：出生時の循環器系の適応生理. 小児科 2000; 41; $2225-2231$

13) Momma K, Ando M, Takao A: Fetal cardiac morphology of tetralogy of Fallot with absent pulmonary valve in the rat. Circulation 1990; 82: 1343-1351

14）門間和夫：ラット胎仔先天性心疾患の断面像 : 胎児心工 コーのための染色体 $22 \mathrm{q} 11$ 欠失症候群モデル動物図譜と して. 日小児循環器会誌 2018 ; 34:55-62

15）門間和夫：動脈管の収縮形態：ラット動脈管断面像天然 色図譜. 日小児循環器会誌 $2018 ; 34: 128-134$

16) Hebel R, Stromberg MW: Anatomy and Embryology of the Laboratory Rat. Wörthsee, BioMed Verlag, 1986, pp $112-113$

17) Anderson RH, Brown NA, Webb S: Development and structure of the atrial septum. Heart 2002; 88: 104-110 